\title{
Control measures recommended for goat gastrointestinal nematode infections after analysis of infection dynamics in the semiarid region of Brazil
}

\author{
Vanessa Diniz Vieira ${ }^{1}$ (D) Franklin Riet Correa ${ }^{1,2}$ Vinícius Longo Ribeiro Vilela ${ }^{1,3, *}$ \\ Márcia Alves de Medeiros $^{1}$ Jouberdan Aurino Batista ${ }^{1}$ (D) Sergio Santos Azevedo ${ }^{1}$ (D) \\ Dayana Firmino de Morais $^{4}$ (D) Lídio Ricardo Bezerra de Melo ${ }^{1}(\mathbb{D})$ \\ Samara dos Santos Silva ${ }^{4}$ Thais Ferreira Feitosa ${ }^{3}$ (D)
}

${ }^{1}$ Programa de Pós-graduação em Ciência e Saúde Animal, Universidade Federal de Campina Grande (UFCG), Patos, PB, Brasil.
${ }^{2}$ Instituto Nacional de Investigación Agropecuaria (INIA), La Estanzuela, Colonia, Uruguay.
${ }^{3}$ Departamento de Medicina Veterinária, Instituto Federal da Parába (IFPB), 8800-970, Sousa, PB, Brasil. E-mail: vinicius.vilela@ifpb.edu.br.
"Corresponding author.
${ }^{4}$ Programa de Pós-graduação em Ciência Animal, Universidade Federal de Campina Grande (UFCG), Patos, PB, Brasil.

ABSTRACT: This study aimed to determine control measures for gastrointestinal nematodes in goats in the northeastern semiarid after analyzing the dynamics of gastrointestinal helminths during the drought, the evolution of the parasitic load after the first rains and the differences in susceptibility between goats of different categories and ages. Five farms were studied from March 2013 to January 2015 . Feces were collected from all goats every month, for fecal egg counts (FECs). No treatment was required on any farm during the dry period. In 2013 , with annual rainfall of 265-533 mm, treatments were not necessary during the rainy season. However, in 2014, with rainfall of 604-778 mm, treatments were necessary 60-90 days, after the first rains. On three farms, gastrointestinal nematodes showed multiple anthelmintic resistance. The FECs from lactating goats were significantly higher than from dry and young goats. In conclusion, in the Brazilian semi-arid region (Caatinga biome), it is generally unnecessary to treat grazing goats during the dry season. In the rainy season, the parasite load increases 2-3 months after the first rains. In both, the dry and the rainy season, farmers should monitor their herds by means of FEC or another criterion (anemia or submandibular edema), to determine the need to treat.

Key words: anthelmintic treatmen, dairy goats, gastrointestinal nematodes.

Medidas de controle recomendadas para as infecções por nematódeos gastrintestinais de caprinos após análise da dinâmica das infecções no semiárido do Brasil

RESUMO: Este trabalho objetivou determinar medidas de controle de nematódeos gastrintestinais de caprinos no semiárido nordestino após análise da dinâmica das infecções helmínticas durante a seca, a evolução da carga parasitária após as primeiras chuvas e as diferenças de susceptibilidade entre caprinos de distintas categorias e idades. Em cinco propriedades, de março de 2013 a janeiro de 2015 , foram coletadas, mensalmente, fezes de todos os caprinos para contagem de ovos. Em nenhuma propriedade foi necessário vermifugar durante os períodos de seca. Em 2013, com precipitações de 265-533 mm anuais, não foi necessário vermifugar durante o período de chuva. No entanto, em 2014, com precipitações de 604-778 mm, foi necessário vermifugar 60-90 dias após as primeiras chuvas em três propriedades. Nessas três propriedades foi encontrada multirresistência aos anti-helmínticos. Foi constatado que o OPG das cabras lactantes foi significativamente maior do que o OPG das cabras secas e dos cabritos. Em conclusão, na região semiárida, geralmente, não é necessário o tratamento das cabras pastejando na caatinga durante a estação seca. Na estação chuvosa, a carga parasitária aumenta 2-3 meses após as primeiras chuvas. Tanto na seca quanto nas chuvas, o produtor deve monitorar o rebanho mediante OPG ou por outros critérios (anemia, edema submandibular) para determinar a necessidade de vermifugação.

Palavras-chave: cabras leiteiras, nematódeos gastrintestinais, tratamento anti-helmíntico.

\section{INTRODUCTION}

Brazilian goat herd has about 11 million animals, most of which belongs to Northeastern region, with $94 \%$ of the goats. Paraíba state in the Northeast region is the fifth largest in number of goats, with approximately 650,000 heads (IBGE,
2018). The Northeast of this state is mainly semiarid (approximately 74\%) and the goats there are adapted to conditions of high temperature, irregular rainfalls and periodic droughts (CORREIA et al., 2011).

Goat farming plays an important socioeconomic role for rural producers, as it provides them with direct income; in addition, it represents 
a food source, with high quality products and high biological value (COSTA et al., 2011). However, the high prevalence of gastrointestinal nematodes and anthelmintic resistance makes the effective control of these helminths difficult. They are the main problem for goat and sheep production in the Brazilian semiarid region (RIET-CORREA et al., 2013b; VIEIRA et al., 2014). Several factors contributed to the development of anthelmintic resistance in this region, such as the indiscriminate use of anthelmintics, due to the lack of knowledge by producers, poor management practices and easy drug purchase (SILVA et al., 2018).

In the semi-arid region, during long periods, it was recommended for the control of gastrointestinal helminthiasis, that goats and sheep should be treated four times a year, three during the dry period and one during the rainy period (EMBRAPA, 1994; GUIMARÃES FILHO \& ATAÍDE COSTA, 2010; CODEVASF, 2011). Although, one important measure for preventing anthelmintic resistance is to avoid treatments or to treat as little as possible during the dry period. However, even during the dry season, infections due to gastrointestinal parasites may require treatment (VILELA et al., 2012).

On dairy goat farms in the semi-arid region of Paraíba, with multi-resistant gastrointestinal nematodes, it has been demonstrated that gastrointestinal helminths can be controlled by means of monthly fecal egg counts (FECs) followed by selective treatments on lactating, dry or young goats at different times when the FEC is between 500 and 1000 eggs (RIET-CORREA et al., 2013a). Selective treatment consists of deworm only animals with a high parasitic load and/or presenting clinical signs of gastrointestinal helminthiasis, such as anemia, submandibular edema and low body condition. Reduction in the number of treatments decreases the selection pressure for resistant individuals, conserving in greater quantity, nematodes that do not come into contact with the anthelmintic (refugia population) (TORRES-ACOSTA \& HOSTE, 2008).
To determine the need for treatments during the dry season, it is also important to study the epidemiology of gastrointestinal helminths during this period and to ascertain the susceptibility to gastrointestinal nematodes of different categories of goats (lactating, dry and young). Therefore, this study aimed to determine the epidemiological aspects of goat gastrointestinal nematodes in the Brazilian semiarid region during the dry season, the time required to start anthelmintic treatment after the onset of rainfall in the region, and the susceptibility differences between lactating, dry and young goats.

\section{MATERIALS AND METHODS}

This study was conducted on five farms in the municipalities of Amparo (farms F1 and F5), Ouro Velho (F2), Prata (F3) and Maturéia (F4), in the semi-arid region of Paraíba, from March 2013 to January 2015. Information on the pluviometry of the municipalities was gathered from the website of the Paraíba Water Management Executive Agency (AESA, 2017). The annual rainfall of the four municipalities over the period from 2011 to 2014 is presented in table 1.

Dairy herds, including lactating, dry and young goats, were composed of the following average number of animals on each farm with the range during the study period: F1, 52 goats (46-63); F2, 38 goats (25-40); F3, 15 goats (11-20); F4, 37 goats (25-42); and $\mathrm{F} 5,20$ goats $(9-25)$.

Every farm was visited monthly for clinical evaluation of the herds and fecal sample collection from all the goats. After collection, the samples were sent to the Laboratory of Parasitic Diseases of Domestic Animals (LPDDA), Universidade Federal de Campina Grande (UFCG), in Patos, state of Paraíba. Goats of different ages were generally mixed in single herds. Fecal egg counts (FECs) (GORDON $\&$ WHITLOCK, 1939) were performed on individual

Table 1 - Cumulated annual rainfalls ( $\mathrm{mm})$ in the municipalities of Amparo, Ouro Velho, Prata and Matureia.

\begin{tabular}{|c|c|c|c|c|}
\hline \multirow[t]{2}{*}{ Year } & --------- & ------------------ & lity----- & -------------- \\
\hline & Amparo & Ouro Velho & Prata & Maturéia \\
\hline 2011 & 903.7 & 930.3 & 778.8 & NR \\
\hline 2012 & 117.8 & 149.5 & 152.8 & NR \\
\hline 2013 & 264.8 & 310 & 445.7 & 533.3 \\
\hline 2014 & 615.2 & 612.6 & 603.9 & 777.9 \\
\hline
\end{tabular}

Ciência Rural, v.50, n.11, 2020. 
samples, while larval cultures (ROBERTS \& O'SULLIVAN, 1950) were performed on pooled samples from each farm. Larvae were identified according to the morphological criteria recommended by KEITH (1953). For FECs and treatments, each herd was divided in three groups: lactating, dry and young goats. Selective treatments on all animals in each group were performed when the mean FEC of the group was above 1000 eggs, and the anthelmintic dosage occurred observing the individual weight of the animals.

The fecal egg count reduction test (FECRT) (COLES et al., 1992) was performed to evaluate resistance of gastrointestinal nematodes to anthelmintics in the herds that presented more than 500 eggs per gram of feces (EPG). For this test, five groups of 5-10 goats, depending on the number of goats on the farm, were used. Four groups were treated orally with a different anthelmintic each: albendazole $10 \%$ - Ibazole $10 \%{ }^{\circledR} /$ Ibasa (4 mg/kg); moxidectin $0.2 \%$ - Cydectin ora ${ }^{\circledR} /$ Fort Dodge $(0.5 \mathrm{mg} / \mathrm{kg}$ body weight); Levamisole hydrochloride 5\% - Ripercol $\AA /$ Fort Dodge ( $5 \mathrm{mg} / \mathrm{kg}$ body weight); closantel $10 \%$ - Diantel ${ }^{\circledR} /$ Hipra $(10 \mathrm{mg} / \mathrm{kg})$; and the fifth was the control group. Fecal samples were collected before and 7-10 days after treatment to verify the efficacy of the drugs. The formula used to calculate the efficacy of the anthelmintic was:

$\%$ efficacy $=[1-(\mathrm{T} 1 / \mathrm{T} 0) \times(\mathrm{C} 1 / \mathrm{C} 0)] \times 100$

$\%$ efficacy $=1-\left(\frac{T 1}{T 0} \times \frac{C 0}{C 1}\right) \times 100 \mathrm{~T} 1=\mathrm{FEC}$ in the

treated group on day 7-10; T0 $=$ FEC in the treated group on day zero; $\mathrm{C} 0=\mathrm{FEC}$ of the control group on day zero; $\mathrm{C} 1=\mathrm{FEC}$ of the treated group on day 7-10. The FECRT was not performed on the farms F3 and F5 farms, because at no time did the animals exceed an average of 500 EPG.

Numbers of eggs in each group of goats were subjected to analysis of variance (ANOVA) using the Friedman test with a $95 \%$ confidence interval, through the BioEstat software (AYRES et al., 2007).

\section{RESULTS}

In the year 2013, which was unusually dry (Table 1), it was not necessary to deworm the goats on any of the farms, even during the rainy season. In 2014 , it was not necessary to deworm any farm during the dry season because the FEC remained below 500 . However, in the same year, 60 to 90 days after the first rains, on farms 1, 2 and 4, the FEC increased to above 1000; and it therefore, became necessary to deworm the animals. Figure 1 presents the FEC results and the rainfall on the five farms studied.
On farm 1, anthelmintic treatment was not necessary during the first 14 months of the trial. In the second year, during the rainy season, 60 days after rainfall of $144.8 \mathrm{~mm}$, the mean FEC increased from 110.6 to 2194 , and was greater than 1000 in all groups. An initial deworming was indicated for the whole herd. The farmer administered moxidectin, which had not been used for two years, but 10 days later the FECRT showed that the efficiency of this anthelmintic was only $64 \%$ (Table 2). Following this, levamisole was recommended, which had an efficiency of $93.6 \%$. However, the farmer only treated a few animals after this test, because of a lack of resources, and it was necessary to treat the entire herd 30 days later.

On farm 2, deworming was not necessary for the first 17 months. However, in 2014, the parasite load of the goats increased 90 days after the first rainfall $(110 \mathrm{~mm})$, such that the FEC of the lactating goats increased to 1256 . Thus, a single selective deworming procedure was required for the lactating goats: $10 \%$ albendazole was used, with efficacy of $92 \%$ (Table 2). The FECs of the dry and young goats remained at zero.

On farm 3, with 15 goats, the FEC was zero throughout the study. When rainfall occurred, the mean EPG increased to 162, with no need to deworm at any time during the entire experimental period.

On farm 4, after 60 days of the first rainfall $(103 \mathrm{~mm})$, the mean EPG increased from 358 to 1356.7 , and became greater than 1000 in all groups. Moxidectin was administered to all goats, with $82 \%$ efficacy (Table 1). No further deworming was necessary on this farm. In September 2014, the farmer sold the entire herd.

On farm 5, no deworming was required at any time during the entire experimental period. The mean FEC varied from 0 to 300 . The highest FEC was 300 , in lactating goats 60 days after rainfall of $66.1 \mathrm{~mm}$. In September 2014, the farmer sold the entire herd.

Differences in susceptibility to gastrointestinal nematodes were observed among the animal groups. The mean EPG of the lactating goats $(259 \pm 169)$ was significantly higher $(\mathrm{P}<0.05)$ than dry goats $(157 \pm 162)$ and young goats $(105 \pm 131)$, with no differences between dry and young goats.

In the FECRTs performed on three of the five farms (F1, F2 and F4), varying degrees of multiple anthelmintic resistance to all the active agents tested was observed (Table 2). Despite this, through using the drug that was shown in the FECRT to be most efficient, no clinical signs of gastrointestinal 

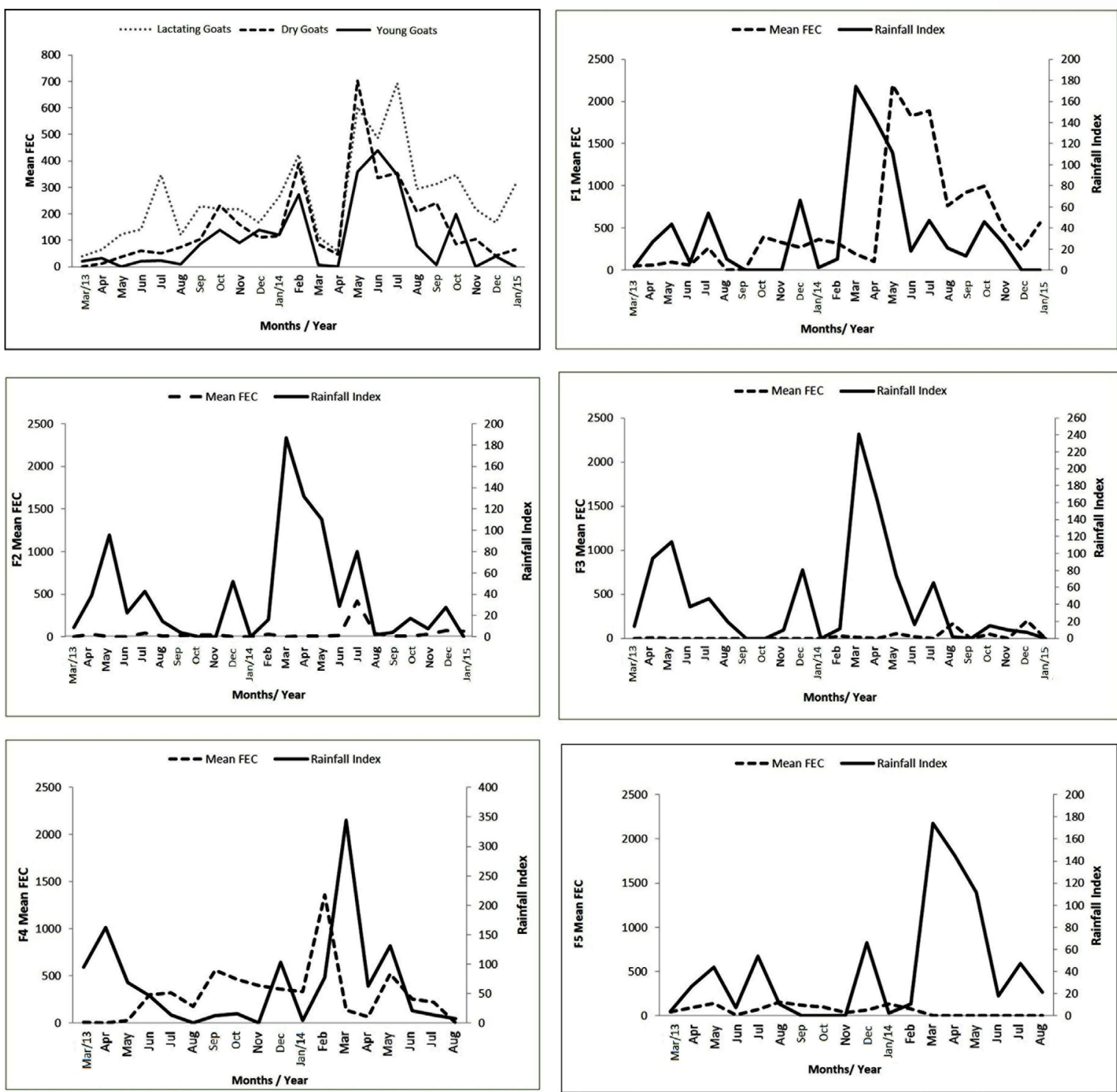

Figure 1 - (A) Mean FEC in the different groups of goats on five farms in the semi-arid region of Paraiba from March 2013 to January 2015; Mean FEC and rainfall from March 2013 to January 2015 on Farm 1 in the municipality of Amparo (B); Farm 2 in the municipality Ouro Velho (C); Farm 3 in the municipality of Prata (D); Farm 4 in the municipality of Matureia (E); Farm 5 in the municipality of Amparo, Paraíba (F). 
Table 2 - Results of fecal egg count reduction test in three farms of dairy goats in the semi-arid Brazilian region between March 2013 and January 2015.

\begin{tabular}{|c|c|c|c|}
\hline Year 2013 & F1 (\%) & $\mathrm{F} 2(\%)$ & $\mathrm{F} 4(\%)$ \\
\hline Moxidectin $0,2 \%$ & 64 & 10 & 80 \\
\hline Closantel 10\% & 79.9 & 64 & 50.2 \\
\hline Albendazole $10 \%$ & 73.9 & 90 & 78.5 \\
\hline Levamisole Hydrochloride 5\% & 93.6 & 0 & 30 \\
\hline Year 2014 & F1 ( $\%)$ & $\mathrm{F} 2(\%)$ & $\mathrm{F} 4(\%)$ \\
\hline Moxidectin $0,2 \%$ & 60 & 30 & 82 \\
\hline Closantel 10\% & 74 & 70 & 52.5 \\
\hline Albendazole $10 \%$ & 92 & 92 & 80 \\
\hline Levamisole Hydrochloride 5\% & 79.5 & 20 & 50 \\
\hline Year 2015 & F1 (\%) & $\mathrm{F} 2(\%)$ & F4 $(\%)^{*}$ \\
\hline Moxidectin $0,2 \%$ & 50.2 & 50.6 & - \\
\hline Closantel 10\% & 70.8 & 75 & - \\
\hline Albendazole $10 \%$ & 86 & 93.5 & - \\
\hline Levamisole Hydrochloride 5\% & 80 & 73 & - \\
\hline
\end{tabular}

$\mathrm{F}=$ Farm; ${ }^{*}$ analysis not performed because in September 2014, the farmer sold the entire herd.

helminthiasis were observed during the periods when the farms presented FECs higher than 1000. No resistance tests were performed on farms 3 and 5 , since the average FEC did not exceed 500.

On average, the be most prevalent helminth species through the fecal cultures on samples from all the farms was Haemonchus contortus (89\%), followed by Trichostrongylus colubriformis (8.6\%), Strongyloides papillosus (1.3\%) and Oesophagostomum columbianum (1.1\%).

\section{DISCUSSION}

One important finding from this study was that it was not necessary to deworm dairy goats grazing in the Caatinga biome during periods of drought, on any of the small family farms investigated. Moreover, only in three farms was it necessary to deworm the goats during the rainy season. On the other two farms, no deworm was required at any time during the entire period. This situation may have occurred because one of the years of the study (2013) was drier than normal, while in 2014 the rainfall was normal (Table 1). The situation would probably be different in two years with normal rains. In a previous study on eight farms in the same region monitored by means of FEC, the number of treatments during the rainy season was $2.3 \pm 1.1$ and during the dry season it was $1.5 \pm 0.8$ (RIET-CORREA et al., 2013b). These variations from one year to another, as occurred in this trial between 2013 (dry) and 2014 (normal), suggested that to control gastrointestinal nematodes in the semi-arid region, is necessary to consider the rainfall in the region.

Another finding from this study is that, 2-4 months after the first rains, there is an increase in FECs. The relationship between the number of eggs in faces and rainfall was also found by OLIVEIRA et al. (2018), in goats in Ceará State, with increase of the EPG in the rainy season. This was already expected because larval development depends on the temperature and humidity of the environment, so in the rainy season there is an increase in pasture infestation (CRAIG, 2018). This requires either selective treatment or treatment of all goats in the herds in which the FEC exceeds 1000 . However, it was only on Farm 1 that more than one treatment was necessary. These results suggested that 3060 days after the first rains, farmers should remain alert to avoid possible occurrences of helminthiasis. Deworming should be implemented as soon as an increase in FEC occurs or when the first signs of gastrointestinal nematodes appear (submandibular edema, anemia, lower weight gains, loss of body condition or bad hair condition).

It was also reported that lactating goats were more susceptible to gastrointestinal nematodes than dry and young goats. This information is important in that it allowed farmers to apply selective 
treatment that takes the animals' physiological stage or age into consideration. Higher susceptibility among high-production lactating goats had already been observed in Europe (CHARTIER \& HOSTE, 1997; HOSTE et al., 2002).

In the three farms on which the FECRT was performed, multiresistance was observed. Multiresistance to anthelmintics is a widespread problem in the Brazilian semi-arid region, including the region where this study was conducted (RIET-CORREA et al., 2013a). This situation is most probably a consequence of excessive numbers of deworming procedures at times when the environmental conditions are not favorable for the parasites in refugia. One important problem for farmers that inhibits use of fewer anthelmintic treatments is the economic difficulty in performing FECs.

Additionally, in the dry season, goats normally lose weight due to food shortages and farmers often interpret these losses as being caused by gastrointestinal helminthes; and consequently, drench the whole herd. One solution is to encourage farmers to use other criteria to determine the need for deworming. Given that haemonchosis is the most prevalent parasitic disease, such criteria could comprise the degree of anemia or the presence of submandibular edema. Another alternative is to use FAMACHA: in a previous study on dairy goat farms in the same region, use of FAMACHA resulted in $1.2 \pm 1.5$ drenching per year (RIETCORREA et al., 2013b).

\section{CONCLUSION}

It can be concluded that in the semiarid region, it is generally unnecessary to treat gastrointestinal nematodes in goats grazing in the Caatinga during the dry season. However, farmers need to monitor their herds by means of FEC or other characteristics (anemia, submandibular edema or hair condition), to determine the need for treatment. During the rainy season, FECs increase and it may be necessary to implement treatment 2-4 months after the first rains, mainly because lactating goats are more susceptible to gastrointestinal helminths than dry and young goats.

\section{ACKNOWLEDGEMENTS}

The authors would like to thank Coordenação de Aperfeiçoamento de Pessoal de Nível Superior (CAPES) and Conselho Nacional de Desenvolvimento Científico e Tecnológico
(CNPq), Brazil, for the fellowship to V.D.V. and S.S.A., respectively. We also would like to acknowledge the farmers who allowed the use of their animals during the experiment.

\section{BIOETHICS COMMITTEE APPROVAL}

The study was approved by the Animal Care and Ethics Committee, Universidade Federal de Campina Grande, Patos, Paraíba, Brazil (Approval number: 23000,000525,2015/38).

\section{DECLARATION OF CONFLICTS OF INTERESTS}

The authors declare no conflict of interest. The funding sponsors had no role in the design of the study; in the collection, analyses, or interpretation of data; in the writing of the manuscript, and in the decision to publish the results.

\section{AUTHORS' CONTRIBUTIONS}

All authors contributed equally for the conception and writing of the manuscript. All authors critically revised the manuscript and approved of the final version.

\section{REFERENCES}

AESA - Agência Executiva de Gestão das Águas. Informação [online]. 2011-2014 Available from: <http://www.aesa.pb.gov.br>. Accessed: Jan. 11, 2017.

AYRES, M. et al. BioEstat 5.0: aplicações estatísticas nas áreas das ciências biológicas e médicas. 4. ed. Belém: Sociedade Civil Mamirauá, 2007. 364p.

CHARTIER, C.; HOSTE, H. Repeated infections with Haemonchus contortus and Trichostrongylus colubriformis in dairy goats: comparison of resistant and susceptible animals. Parasitology Research, v.84, n.3, p.249-253, 1997. Available from: <https://link. springer.com/article/10.1007\%2Fs004360050390>. doi: 10,1007 / s004360050390. Accessed: Feb. 12, 2020.

CODEVASF. Manual de Criação de Caprinos e Ovinos. Brasília: Codevasf, 2011. 142p.

COLES, G. C. et al. World Association for the Advancement of Veterinary Parasitology (WAAVP) methods for the detection of anthelmintic resistance in nematodes of veterinary importance. Veterinary Parasitology, v.44,p.35-44, 1992. Available from: $<$ https:// www.sciencedirect.com/science/article/abs/pii/030440179290141U>. Accessed: Jan. 13, 2017. doi: 10.1016/0304-4017(92)90141-U.

CORREIA, R.C. et al. A região semiárida brasileira. In: VOLTOLINI, T. V. Produção de caprinos e ovinos no Semiárido. Petrolina: Embrapa Semiárido, 2011. Cap. 1, p. 21-48.

COSTA, V. M. M. et al. Gastro-intestinal nematodes control in goats and sheep in the semiarid region northeastern Brazil. Pesquisa Veterinária Brasileira, v.31, n.1, p.65-71, 2011. Available from: $<$ http://www.scielo.br/pdf/pvb/v31n1/10.pdf $>$. Accessed: Jan. 13, 2017. doi: 10.1590/S0100-736X2011000100010. 
CRAIG, T. M. Gastrointestinal nematodes: diagnosis and control. Veterinary Clinics of North America: Food Animal Practice, v.34, n.1, p.185-199, 2018. Available from: $<$ https://doi. org/10.1016/j.cvfa.2017.10.008>. Accessed: Mar. 02, 2020.

EMBRAPA. Recomendações tecnológicas para a produção de caprinos e ovinos no Estado do Ceará. Sobral: EMBRAPACNPC. Circular Técnica, 9. 1994. 58p.

GORDON, H. M.; WITHLOCK, H. V. A new tecnique for counting nematode eggs in sheep faeces. Journal of the Council for Scientific and Industrial Research, v.12, n.1, p.50-52. 1939. Avaliable from: <https://www.cabdirect.org/cabdirect/ abstract/19390800035>. Accessed: Jan. 13, 2017.

GUIMARÃES FILHO, C.; ATAÍDE JÚNIOR, J. R. Manejo Básico de Ovinos e Caprinos. Brasília: SEBRAE, 2010. 137p.

HOSTE, H. et al. Targeted application of anthelmintics to control trichostrongylosis in dairy goats: result from a 2-year survey in farms. Veterinary Parasitology, v.110, p.101-108, 2002. Available from: <https://doi.org/10.1016/S0304-4017(02)003072>. Accessed: Feb. 26, 2020.

IBGE - SIDRA Sistema IBGE de Recuperação Automática. Pesquisa de Pecuária Municipal [online]. 2018. Available from: $<$ https://sidra.ibge.gov.br>. Accessed: Mar. 15, 2020.

KEITH, R. K. Differentiation of infective larval of some common nematode parasites of cattle. Australian Journal of Zoology, v.1, n.2, p.223-235, 1953. Available from: <https://www.publish.csiro.au/ zo/ZO9530223 > . Accessed: Feb. 20, 2020. doi: 10.1071/ZO9530223.

OLIVEIRA, D. A. S. et al. Gastrointestinal parasites in goats from Quixadá, Ceará. Pesquisa Veterinária Brasileira, v.38, n.8, p.1505-1510, 2018. Available from: <http://www.scielo.br/pdf/ pvb/v38n8/1678-5150-pvb-38-08-1505.pdf $>$. Accessed: Feb. 26, 2020. doi: 10.1590/1678-5150-pvb-4828.

RIET-CORREA, B. et al. Productive systems of dairy goats in the semiarid of Paraiba: characterization, major limiting factors and evaluation of intervention strategies. Pesquisa Veterinária Brasileira, v.33, n.3, p.345-352, 2013a. Available from: < http:// www.scielo.br/pdf/pvb/v33n3/12.pdf >. Acessed: Feb. 18, 2020. doi: 10.1590/S0100-736X2013000300012.

RIET-CORREA, B. et al. Dairy goat production in the Brazilian semiarid region: integrated gastrointestinal nematodes control to overcome anti-helminthic resistance. Pesquisa Veterinária Brasileira, v.33, n.7, p.901-908, 2013b. Available from: <http:// www.scielo.br/pdf/pvb/v33n7/10.pdf $>$. Accessed: Feb. 18, 2020. doi: 10.1590/S0100-736X2013000700010.

ROBERTS, F. H. S; O'SULLIVAN, J. P. Methods for egg counts and larval cultures for strongyles infesting the gastrointestinal tract of cattle. Australian Journal of Agricultural Research, v.1, n.1, p.99-102, 1950. <http://dx.doi.org/10.1071/AR9500099>. Accessed: Feb. 22, 2020.

SILVA, F. F. et al. Nematode resistance to five classes in naturally infected sheep herds in Northeastern Brazil. Revista Brasileira de Parasitologia Veterinária, v.27, n.4, p.423-429, 2018. Available from: <http://www. scielo.br/pdf/rbpv/v27n4/1984-2961-rbpv-S1984-296120180071.pdf >. Accessed: Feb. 02, 2020. doi: 10.1590/s1984-296120180071.

TORRES-ACOSTA J. F. J.; HOSTE, H. Alternative or improved methods to limit gastro-intestinal parasitism in grazing sheep and goats. Small Ruminant Research, v.77, p.159-173, 2008. Available from: $<$ https:// doi.org/10.1016/j.smallrumres.2008.03.009>. Accessed: Feb. 14, 2020.

VIEIRA, V. D. et al. Prevalence and risk factors associated with goat gastrointestinal helminthiasis in the Sertão region of Paraíba State, Brazil. Tropical Animal Health Productioin, v.46, p.355-361, 2014. Available from: <https://link.springer. com/article/10.1007\%2Fs11250-013-0496-y>. Accessed: Dec. 10, 2019. doi: 10.1007 / s11250-013-0496-y.

VILELA, V. L. et al. Biological control of goat gastrointestinal helminthiasis by Duddingtonia flagrans in a semi-arid region of the northeastern Brazil. Veterinary Parasitology, v.188, p.127-133, 2012. Available from: <https://doi.org/10.1016/j. vetpar.2012.02.018>. Accessed: Feb. 14, 2020. 